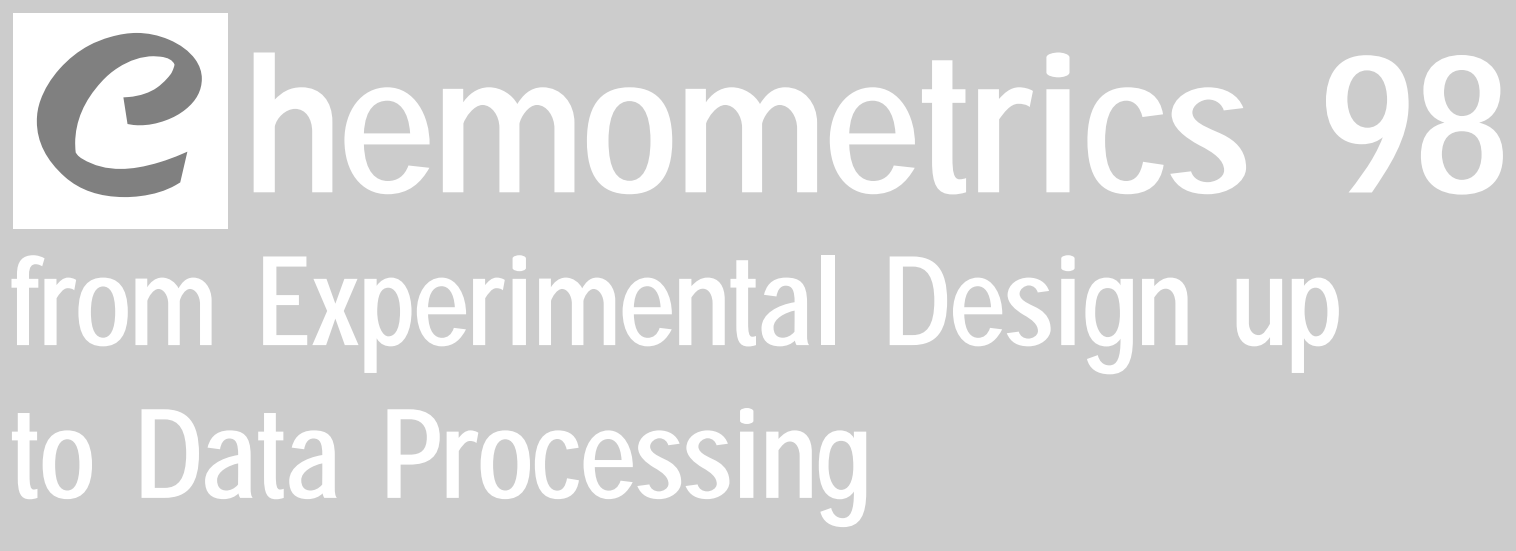

\title{
What is Chemometrics?
}

T

here is no short and general definition of Chemometrics which has been widely accepted up to now. This illustrates that this young discipline covers in fact a large field of applications for which the so-called Chemometricians are, most often, specialists of a limited area. So, most Chemometricians claim to be specialists only of one of the two major areas: (i) Data Processing or (ii) Experimental Design. In fact, as for any major scientific discipline which are generally divided in several fields, e.g. theoretical chemistry and medicinal chemistry, vegetal biology and animal biology, there is a large gap between the above major areas (i) and (ii) in Chemometrics.

At the early beginning, in the 70's and 80's Chemometrics was understood as "Data processing in Chemistry". Nowadays due to the evolution of the covered field a more general title has to be proposed. Up to now the shortest and general definition of Chemometrics that could be suggested is:

\section{Chemometrics: The Science of Processing} the Chemical Information.

Actually Chemometrics is a real discipline with its own Concepts, its Methodologies and large field of applications. These latter are covering a large variety of fields in Chemistry: from process and quality control in chemical industry up to computer aided design in medicinal chemistry, for example. If it is well known that the Concepts are based on Mathematics and Statistics and that the Methodologies are based on Computer Sciences, it is not so obvious to find the
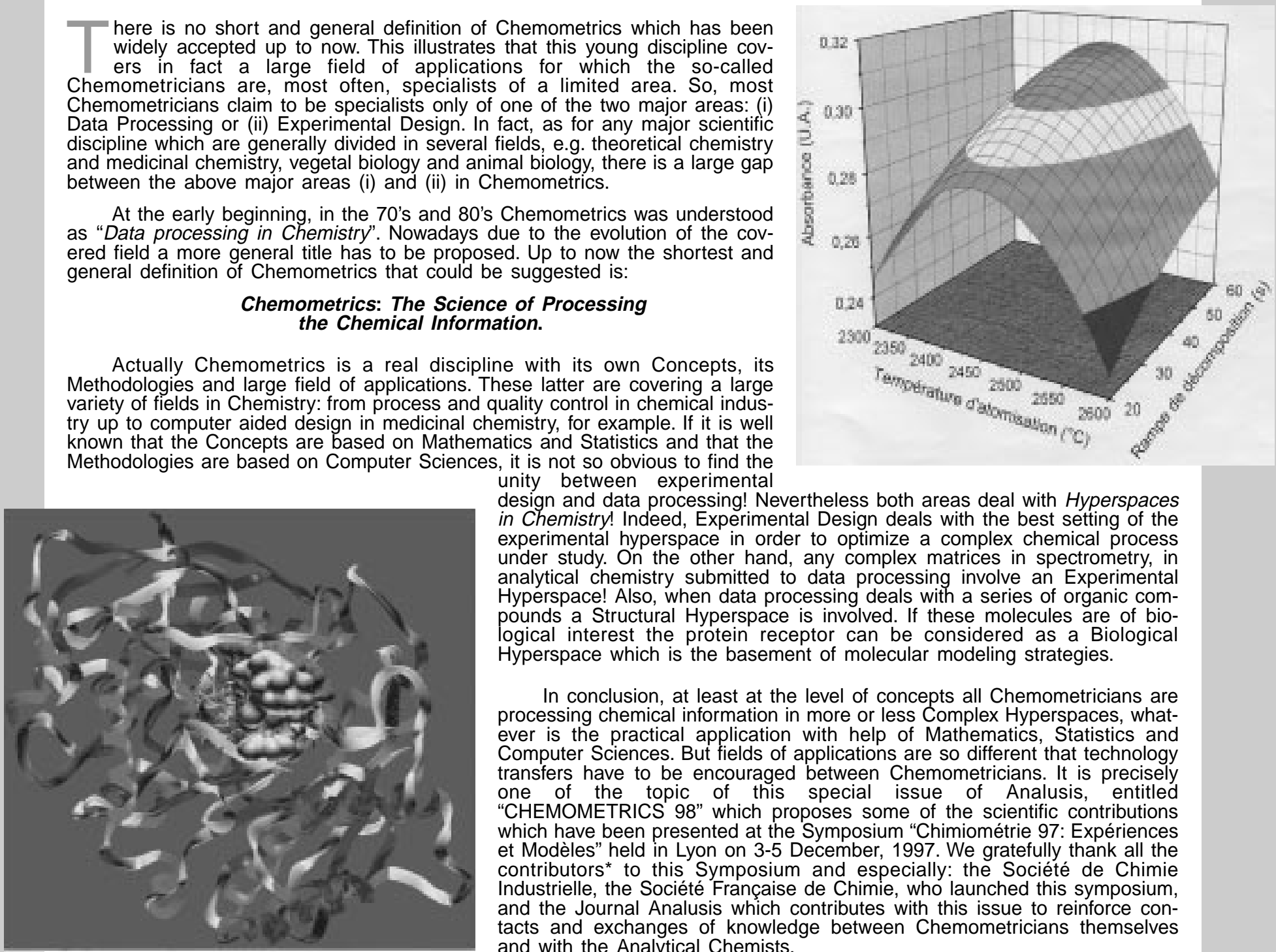
unity between experimental design and data processing! Nevertheless both areas deal with Hyperspaces in Chemistry! Indeed, Experimental Design deals with the best setting of the experimental hyperspace in order to optimize a complex chemical process under study. On the other hand, any complex matrices in spectrometry, in analytical chemistry submitted to data processing involve an Experimental Hyperspace! Also, when data processing deals with a series of organic compounds a Structural Hyperspace is involved. If these molecules are of biological interest the protein receptor can be considered as a Biological Hyperspace which is the basement of molecular modeling strategies.

In conclusion, at least at the level of concepts all Chemometricians are processing chemical information in more or less Complex Hyperspaces, whatever is the practical application with help of Mathematics, Statistics and Computer Sciences. But fields of applications are so different that technology transfers have to be encouraged between Chemometricians. It is precisely one of the topic of this special issue of Analusis, entitled "CHEMOMETRICS 98" which proposes some of the scientific contributions which have been presented at the Symposium "Chimiométrie 97: Expériences et Modèles" held in Lyon on 3-5 December, 1997. We gratefully thank all the contributors* to this Symposium and especially: the Sociéte de Chimie Industrielle, the Société Française de Chimie, who launched this symposium, and the Journal Analusis which contributes with this issue to reinforce contacts and exchanges of knowledge between Chemometricians themselves and with the Analytical Chemists. 


\section{Dossier}

\section{Chimiométrie 98}

M 13 Avant-Propos

J.R. Chrétien et R. Verwaerde (Laboratoire de Chimiométrie, Faculté des Sciences, Université d'Orléans, Orléans, France et Saint-Just, France)

M 15 Chimiométrie : outils du XXème siècle, méthode du XXIème siècle ?

$P$. Lantéri et $R$. Longeray (Laboratoire de Chimiométrie, Université Caude Bernard-Lyon 1, ESCPE Lyon - CPE Lyon, France)

\section{Plans d'expériences et optimisation}

M 19 Les plans d'expériences en spectrométrie d'absorption atomique : application à la détermination du sélénium G Lespes et M. Potin-Gautier (Université de Pau et des Pays de l'Adour, Laboratoire de Chime Analytique, Pau, France)

M 25 Optimisation et plans d'expériences en spectrométrie d'absorption atomique : dosage rapide de traces de cuivre dans le beurre

D. Hennequin et al. (Équipe de Recherche en Physicochimie et Biotechnologies, IUT de Caen, Université de Caen-Basse Normandie, Département de Génie Chimique, Institut Universitaire de Technologie, Caen, France)

M 30 Étude du relargage des métaux dans les eaux d'infiltration d'un champ d'épandage par construction d'un plan d'expériences $\mathrm{D}$-optimal pondéré

P. Giamarchi et al. (UMR 6521, Département de Chimie, Faculté des Sciences et Techniques, Brest, France)

M 39 Optimisation d'un traitement thermique du bois via un plan factoriel fractionnaire $L$. Duchez et R. Guyonnet (Centre SPIN, Équipe Physico-Chimie des Matériaux, École Nationale Supérieure des Mines de Saint-Étienne, Saint-Étienne, France)

M 44 Application des plans d'expériences à l'analyse de pesticides dans l'eau par chromatographie en phase gazeuse couplée à la spectrométrie de masse J.B. Fournier et al. (Laboratoire Départemental d'Hydrologie et d'Hygiène, Anger, France)

M 53 Étude et optimisation d'un procédé de collage grâce à la méthodologie de Taguchi M. Billiau-Loreau et al. (CNAM, Laboratoire de Chimie Industrielle, Paris, France)

\section{Chimiométrie générale et traitement de données}

M 57 Reconnaissance de l'origine et des modifications d'amidons par traitement chimiométrique de données spectrales F. Vandeerstraeten et al. (LASIR-CNRS et EUDIL, Université des Sciences et Technologies de Lille, Villeneuve d'Ascq, France)

M 63 Analyse en ligne du cuivre et du zinc dans les effluents industriels par spectrométrie UV-visible P. Breuil et al. (Centre SPIN Ecole Nationale Supérieure des Mines de Saint-Étienne, Saint-Éienne, France)

M 67 Apport de la Méthodologie de la Recherche Expérimentale à un modèle de la température de transition vitreuse de polymères acryliques et méthacryliques

P. Camelio et al. (Laboratoire de Stéréochimie, Domaine Universitaire de Saint-Jérôme, Marseille, France)

M 71 Experimental design, sensorial and principal components analysis: Three complementary tools for cocktail optimization

C. Pierlot et al. (Laboratoire d'Oxydation et de Formulation, UPRESA 8009, Villeneuve d'Ascq, France)

ANALUSIS MAGAZINE, 1998, Volume 26, № 8 